\title{
PENGARUH KONSEP DIRI, KECERDASAN DAN PERILAKU KONSUMTIF TERHADAP LITERASI KEUANGAN DI SMK LINGGA KENCANA DEPOK
}

\author{
Siti Nurcahayati \\ Widya Candra Dewi \\ Asridah Warni Tanjung \\ Dosen Fakultas Ekonomi dan Bisnis Universitas Pamulang \\ email :dosen02356@unpam.ac.id, dosen02281@unpam.ac.id, \\ asridarusdan02212@unpam.ac.id
}

\begin{abstract}
ABSTRAK
Penelitian ini bertujuan untuk mengetahui pengaruh konsep diri, kecerdasan, dan perilaku konsumtif terhadap literasi keuangan di SMK Lingga Kencana Depok. Penelitian studi kasus dengan metode deskriptif kuantitatif dengan sampel penelitian 130 responden yang merupakan siswa kelass XI SMK Lingga Kencana Depok. Untuk melihat pengaruh variabel bebas pada variabel terikat, pengolahan data menggunakan software SPSS. Hasil dari penelitian membuktikan konsep diri, kecerdasan, dan perilaku konsumtif berpengaruh penting pada literasi keuangan pada siswa kelas XI SMK Lingga Kencana Depok.
\end{abstract}

Kata Kunci : konsep diri, kecerdasan, perilaku konsumtif, literasi keuangan

\section{ABSTRACT}

This studyaims to determine the effect of self-concept, intelligence, and consumptive behavior on financial literacy at SMK Lingga Kencana Depok. Case study research with quantitative descriptive method with a research sample of 130 respondents who are students of class XI SMK Lingga Kencana Depok. To see the effect of independent variables on the dependent variable, data processing using SPSS software. The results of the study prove that self-concept, intelligence, and consumptive behavior have an important effect on financial literacy in class XI students of SMK Lingga Kencana Depok.

Keyword: self-concept, intelligence, consumptive behavior, financial literacy

\section{PENDAHULUAN \\ 1.1 Latar Belakang}

Perubahan perilaku dan pola hidup manusia mengikuti perjalanan waktu. Tidak sedikit peran globalisasi dalam membentuk karakter masyarakat, lingkungannya sendiri pun sangat memengaruhi, pengaruh baik dan buruk teknologi berkembang dengan sangat pesat dan satu diantaranya adalah teknologi informasi. Kehadiran teknologi yang semakin memudahkan urusan manusia tidak jarang justru membawa ke arah negatif. Teknologi memang buatan manusia, sudah seharusnya manusia mengontrol dan memanfaatkan teknologi dengan benar, 
bukan sebaliknya. Secara tidak langsung manusia dimanfaatkan oleh kehadiran teknologi.

Dalam hal ini, remaja menjadi peran utama pengendalian teknologi dan capaiannya di masa depan. Gaya hidup telah merasuki semua golongan, anakanak, remaja, orang dewasa pun yang sudah lanjut usia. Tidak dapat dipungkiri lagi bahwa gaya hidup remaja masa kini sangat berbeda dengan gaya hidup remaja pada masa yang lalu. Jika dahulu remaja sering menghabiskan waktu dengan membaca buku, kini lebih banyak menghabiskan waktu dengan mengunjungi pusat perbelanjaan dan tempat hiburan untuk mencari kesenangan.

Remaja rentan terhadap perilaku pemborosan jika terdapat dukungan sumber daya keuangan. Remaja menganggap bahwa uang saku yang didapat dari orang tua merupakan pendapatan yang bebas mereka gunakan sesuai keinginan, belanja makanan kesukaan mereka, di resto manapun selagi mampu. Remaja perempuan akan banyak menghabiskan uang sakunya untuk kebutuhan perawatan diri, fashion, makanan, dan mengunjungi lokasi-lokasi populer. Remaja pria akan cenderung menggunakan uang saku untuk membeli video game, kegiatan otomotif, dan hiburan lainnya.

Mereka masih belum mampu membedakan mana yang menjadi kebutuhan dan keinginan, urutan prioritasnya masih sesuai dengan bagaimana mereka mendapatkan kepuasan, bukan berdasarkan keuntungan apa yang akan mereka dapat di masa depan. Literasi keuangan yang rendah menyebabkan remaja kurang memikirkan rencana keuangan jangka panjang dan risiko keuangan yang mungkin dihadapi di masa yang akan datang.
Gaya hidup konsumtif meliputi seluruh remaja siswa SMK. Siswa seharusnya mengisi waktunya dengan menambah pengetahuan, kegiatan positif, sehingga akan memiliki orientasi ke masa depan sebagai manusia yang bermanfaat bagi masyarakat dan bangsa.

Alasan untuk rendahnya tingkat pengetahuan dapat dikaitkan dengan usia muda 18 sampai 22 tahun dari peserta atau di bawah 30 tahun sebagai mayoritas dari mereka berada dalam tahap yang sangat awal siklus dari hidup finansial mereka.

Perilaku konsumtif merupakan kecenderungan seseorang dalam melakukan konsumsi tiada batas, membeli sesuatu secara berlebihan atau tidak terencana. Pola perilaku ini jika terjadi secara terus menerus akan memengaruhi kehidupannya di masa mendatang terkait kedisiplinan dalam mengatur arus kas.

Literasi keuangan akan memengaruhi gaya hidup seseorang untuk mampu mengelola keuangan sehingga terhindar dari perilaku konsumtif. Rendahnya literasi keuangan yang menyebabkan remaja kurang memikirkan rencana jangka panjang, dan risiko keuangan yang mungkin dihadapi di masa yang akan datang. Literasi keuangan memiliki tujuan jangka panjang bagi seluruh golongan masyarakat, yaitu meningkatkan literasi seseorang yang sebelumnya less literate, hanya memiliki pengetahuan tentang lembaga keuangan dan produk lembaga keuangan atau bahkan not literate, menjadi well literate. Artinya tidak hanya memiliki pengetahuan dan keyakinan tentang lembaga keuangan dan produk yang ditawarkan, tetapi juga paham apa saja fitur yang ditawarkan berikut manfaat dan resikonya, serta memiliki keterampilan dalam menggunakan produk dari lembaga keuangan. 


\subsection{Perumusan Masalah}

Perumusan masalah penelitian sebagai berikut:

1. Bagaimana pengaruh "konsep diri terhadap literasi keuangan siswa.

2. Bagaimana kecerdasan terhadap

pengaruh keuangan siswa.

3. Bagaimana pengaruh perilaku konsumtif terhadap literasi keuangan siswa.

4. Bagaimana pengaruh konsep diri, kecerdasan, dan perilaku konsumtif terhadap literasi keuangan siswa.

\subsection{Tujuan Penelitian}

Tujuan penelitian ini untuk mengetahui pengaruh dari konsep diri, kecerdasan, dan perilaku konsumtif baik secara parsial maupun simultan terhadap literasi keuangan siswa kelas XI SMK Lingga Kencana Depok.

\section{TINJAUAN PUSTAKA}

\subsection{Konsep Diri}

Hurlock (dalam Ghufron \& Risnawita, 2011) "mengatakan bahwa konsep diri merupakan gambaran seseorang mengenai diri sendiri yang merupakan gabungan dari keyakinan fisik, psikologis, sosial, emosional aspiratif dan prestasi yang mereka capai”.

\subsection{Kecerdasan}

Menurut Amstrong 2013 "kecerdasan adalah kemampuan untuk menangkap situasi baru serta kemampuan untuk belajar dari pengalaman masalalu seseorang".

Menurut Susanto 2013 "kecerdasan merupakan kemampuan yang dimiliki seseorang untuk melihat suatu masalah lalu menyelesaikannya atau membuat sesuatu yang dapat berguna bagi orang lain".

\subsection{Perilaku Konsumtif}

Menurut Sumartono (dalam Rombe, 2014) "kecerdasan adalah tindakan menggunakan suatu produk secara tidak tuntas yang artinya bahwa belum habis suatu produk dipakai, seseorang telah menggunakan produk jenis yang sama dari merek yang lain atau membeli barang karena adanya hadiah yang ditawarkan atau membeli suatu produk karena banyak yang menggunakan produk tersebut".

Dari beberapa pengertian di atas, maka dapat disimpulkan perilaku konsumtif adalah perilaku membeli dan menggunakan barang yang berdasarkan pada faktor keinginan tanpa mempertimbangkan manfaat dari barang tersebut yang bertujuan untuk memberikan kepuasan dalam dirinya.

\subsection{Literasi Keuangan}

Mendari (2014) "literasi keuangan yaitu kebutuhan dasar bagi setiap individu supaya terhindar dari masalah keuangan".

Menurut Kozina 2015 "literasi keuangan didefinisikan sebagai komponen modal manusia yang digunakan dalam kegiatan keuangan untuk meningkatkan kesejahteraan keuangan individu".

Dari beberapa pengertian di atas, maka dapat disimpulkan literasi keuangan adalah kemampuan yang harus dimiliki manusia dalam mengatur arus keuangannya untuk perencanaan di masa depan.

\subsection{Kerangka Pemikiran}

Berdasarkan uraian tersebut di atas terkait literasi keuangan siswa kelas XI di SMK Lingga Kencana Depok bahwa literasi keuangan dapat ditingkatkan apabila memiliki konsep diri yang baik, kecerdasan yang cukup, dan mampu mengontrol perilaku 
konsumtif, sebagai upaya menciptakan generasi yang mampu mengatasi permasalahan finansial di masa mendatang.

Berikut kerangka pemikiran penelitian :

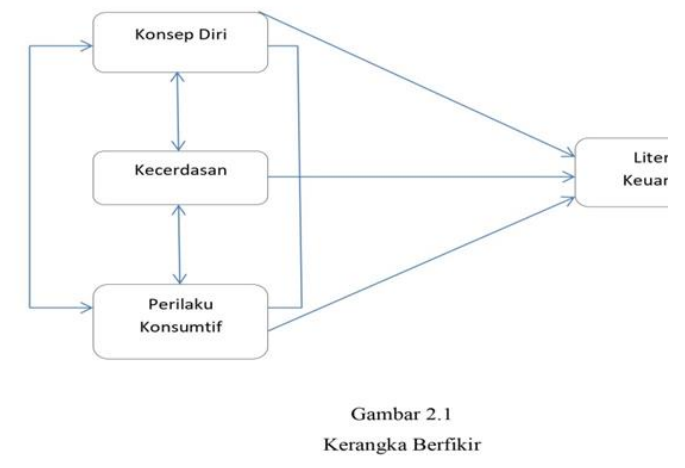

\section{METODOLOGI PENELITIAN}

\subsection{Rancangan Penelitian}

Menurut Sugiyono (2017:2), “ metode penelitian pada dasarnya merupakan cara ilmiah untuk mendapatkan data dengan tujuan dan kegunaan tertentu". Metode penelitian yang dipergunakan dalam penelitian ini adalah metode statistik deskriptif dengan pendekatan kuantitatif.

Menurut pendapat yang dikemukakan oleh Sugiyono (2017:35), “ metode penelitian deskriptif ini dilakukan untuk mengetahui keberadaan variable mandiri, baik hanya pada satu variable atau lebih (variabel berdiri sendiri atau variable bebas) tanpa membuat perbandingan variable itu sendiri dan mencari hubungan dengan variable lain".

\subsection{Populasi dan Sampel Penelitian}

Populasi menurut Sugiyono (2017:215), "populasi adalah jumlah wilayah generalisasi yang terdiri atas objek atau subjek yang mempunyai kualitas dan karakteristik yang di tetapkan oleh peneliti dan kemudian di tarik kesimpulannya".
Berdasarkan tempat dan objek penelitian yang telah di tetapkan oleh peneliti untuk diteliti, maka populasi yang akan di jadikan objek dalam penelitian ini adalah siswa SMK Lingga Kencana.

"Sampel adalah jumlah dan karakteristik yang di miliki oleh populasi tersebut", Sugiyono (2017:215) Teknik sampel yang di gunakan dalam penelitian ini adalah sampling jenuh atau lebih dikenal dengan istilah sensus.

Berdasarkan tempat dan objek penelitian yang telah di tetapkan oleh peneliti untuk diteliti, maka sampel yang akan di jadikan objek dalam penelitian ini adalah siswa kelas 11 SMK Lingga Kencana yang berjumlah 130 orang.

\section{Metode Pengumpulan Data}

Metode pengumpulan data yang di pergunakan di dalam penelitian ini adalah "Cross Sectional", "yaitu suatu metode penelitian dengan cara pendekatan, observasi atau pengumpulan data sekaligus pada suatu saat (Point Time Approach)"., Notoatmodjo, (2010:37).

Menurut Sugiyono (2017:142), "Kuesioner adalah teknik pengumpulan data yang efisien apabila peneliti tahu dengan siapa variabel akan di ukur dan yang di harapkan dari responden. Dalam penelitian ini, kuesioner yang di buat berupa pernyataan dengan jawaban yang mengacu pada skala likert untuk mengukur sikap, pendapat, dan persepsi seseorang atau kelompok orang tentang fenomena sosial. Jawaban dari setiap item instrument sampai sangat negatif, Sugiyono (2017:93)". 


\subsection{Metode Analisis Data}

Teknik analisis data statistika yang di pergunakan di dalam penelitian ini adalah deskriptif kuantitatif dengan mempergunakan bantuan program SPSS versi 16.0. Adapun rancangan uji analisis yang peneliti gunakan adalah sebagai berikut:

\subsubsection{Uji Validitas}

Uji validitas digunakan untuk mengetahui apakah instrumen peneliltian yang digunakan telah memenuhi persyaratan dilihat dari segi kesahihan atau validitas. Menurut pendapat yang dikemukakan oleh Sugiyono (2010:121), "validitas adalah tingkat kehandalan dan kesahihan alat ukur yang digunakan”.

\subsubsection{Uji Reabilitas}

Reliabilitas adalah indeks yang menunjukkan sejauh mana alat pengukur dapat dipercaya atau diandalkan. Bila suatu alat ukur dipakai beberapa kali untuk mengukur gejala yang sama dan hasil pengukuran yang diperoleh relatif konsisten, maka alat pengukur tersebut reliabel.

\subsubsection{Uji Normalitas}

Menurut Sugiyono (2017:239), “uji normalitas digunakan untuk mengkaji kenormalan variabel yang diteliti apakah data tersebut berdistribusi normal atau tidak".

\subsubsection{Uji Multikolinearitas}

Menurut Ghozali (2016:82), “uji multikolinearitas bertujuan untuk menguji apakah model regresi ditemukan adanya korelasi antar variabel bebas (independen)".

\subsubsection{Uji Hipotesis}

Uji hipotesis diperlukan untuk menguji apakah variabel bebas berpengaruh terhadap variabel terikat.

\subsubsection{Uji Regresi Linier Berganda}

Menurut Sugiyono (2017:277), "regresi linier berganda bermaksud meramalkan bagaimana keadaan (naik turunnya) variabel dependen, bila dua atau lebih variabel independen sebagai faktor prediktor dimanipulasi". Jadi analisis regresi berganda akan dilakukan bila jumlah variabel independennya minimal 2

\subsubsection{Uji t}

Menurut Ghozali (2016:84), "pengujian hipotesis secara parsial, dapat diuji dengan menggunakan rumus uji t. Pengujian t-statistik bertujuan untuk menguji ada atau tidaknya pengaruh masing-masing variabel independen (X) terhadap variabel dependen (Y)".

\subsubsection{Uji f}

Menurut Ghozali (2016:85), “uji F pada dasarnya menunjukkan apakah semua variabel independen atau bebas yang dimasukkan dalam model mempunyai pengaruh secara bersamasama terhadap variabel dependen atau terikat".

\section{ANALISA DAN PEMBAHASAN \\ 4.1 Gambaran Umum Lokasi Penelitian}

SMK Lingga Kencana berupaya mengembangkan kurikulum tingkat satuan pendidikan (KTSP) yang semaksimal mungkin mengakomodasi muatan kompetensi sesuai dengan kebutuhan dunia usaha dan dunia industri. Namun dalam pengembangan kurikulum ini, SMK Lingga Kencana tetap berpedoman pada rambu-rambu yang telah digariskan pemerintah melalui Peraturan Mentri Pendidikan Nasional Nomor 22, 23, dan 24 tahun 2006.

\subsection{Analisa Data}


JRNAL ПMПAH

\subsubsection{Hasil Uji Validitas}

Program SPSS versi 16.0 digunakan dalam uji validitas dan reliabilitas setiap instrument dalam sebuah kuesioner penelitian. Pengujian validitas dan reabilitas dengan software SPSS 16.0 bagi 130 siswa dengan jumlah item 36 dengan 8 item untuk variabel $\mathrm{X} 1,10$ unit variabel $\mathrm{X} 2,10$ unit untuk variabel $\mathrm{X} 3$ dan 8 unit untuk variabel $Y$.

Berdasarkan uji validitas terdapat 36 item pertanyaan yang digunakan dalam uji coba kuesioner dan hasilnya terdapat 6 item pertanyaan yang tidak valid karena nilai $r$ hitung lebih kecil dari $r$ tabel dan 30 pertanyaan yang memenuhi kriteria dinyatakan valid. Maka hanya 30 item pertanyaan yang dinilai $r$ hitungnya lebih besar dari $r$ tabelnya yang dapat digunakan dalam penelitian ini.

\subsubsection{Hasil Uji Reabilitas}

\section{Tabel 4.2}

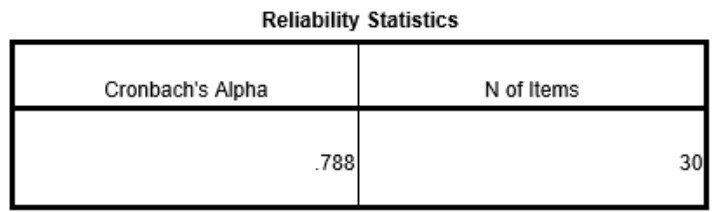

Dari data tabel 4.2 menunjukkan bahwa pada pengujian ini hasil yang didapat adalah nilai cronbach alpha sebesar $0,788>0,60$, maka dapat disimpulkan bahwa ke-30 atau semua pertanyaan kuesioner tersebut adalah reliabel atau konsisten.

\subsubsection{Uji Normalitas \\ Tabel 4.3}

nilai signifikan Asymp.Sig.(2-tailed) senilai $0.087>0.05$ dengan begitu data dalam penelitian ini dapat dinyatakan telah berdistribusi normal.

\subsubsection{Uji Multikoliniaritas}

Tabel 4.4

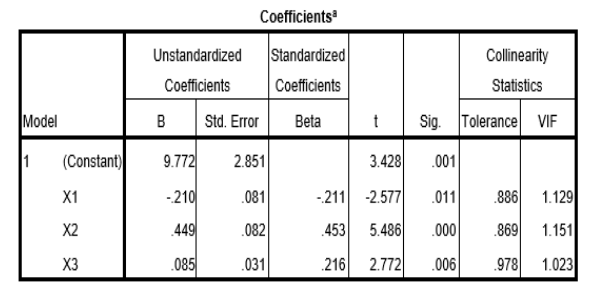

Berdasarkan hasil tabel 4.4 menunjukkan bahwa baik konsep diri, kecerdasan dan perilaku konsumtif memiliki nilai tolerance kurang dari 1 dan VIF memiliki nilai kurang dari 10 maka dapat dikatakan data tidak mengalami multikolinearitas.

\subsubsection{Analisis Regresi Berganda}

Uji Koefisien Determinasi $\mathrm{R}^{2}$

Uji koefisien determinasi untuk mengetahui seberapa besar kontribusi variabel independen (X) terhadap variabel (Y). Pengujian koefisien determinasi menggunakan alat ukur yaitu SPSS

\section{a. Uji Koefisiensi Determinasi $\mathbf{R}^{2}$} Tabel 4.5
One-Sample Kolmogorov-Smirnov Test

\begin{tabular}{|ll|r|}
\hline & & $\begin{array}{r}\text { Unstandardized } \\
\text { Residual }\end{array}$ \\
\hline$N$ & & 130 \\
Normal Parameters & & .0000000 \\
& Mean & 2.36800118 \\
Most Extreme Differences & Absolute & .110 \\
& Positive & .077 \\
& Negative & -.110 \\
Kolmogorov-Smirnov Z & & 1.251 \\
Asymp. Sig. (2-tailed) & & .087 \\
\hline \multicolumn{2}{|c|}{ a. Test distribution is Normal. }
\end{tabular}




\begin{tabular}{|l|r|r|r|r|}
\hline Model Summary \\
\hline Model & \multicolumn{1}{|c|}{$\mathrm{R}$} & $\mathrm{R}$ Square & $\begin{array}{c}\text { Adjusted R } \\
\text { Square }\end{array}$ & $\begin{array}{c}\text { Std. Error of the } \\
\text { Estimate }\end{array}$ \\
\hline 1 & $.505^{\mathrm{a}}$ & .255 & .237 & 2.396 \\
\hline
\end{tabular}

Menurut tabel 4.5 dapat dikatakan uji koefisiensi determinasi $\mathrm{R}^{2}$ besarnya nilai korelasi/hubungan (R) yaitu sebesar 0,505. Menurut table 4.5di atas dapat di ketahui bahwa $\left(\mathrm{R}^{2}\right)$ sebesar 0,255 atau $25,5 \%$.

b. Uji T

Tujuan dari pengujian ini adalah untuk mengetahui pengaruh variabel independen secara individual dalam menjelaskan variasi variabel dependen.

\subsection{Uji F}

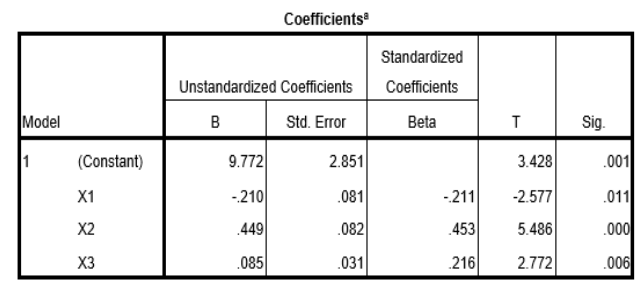

Nilai $t$ hitung yang dihasilkan pada variabel perilaku konsumtif adalah 2,772 dengan sig 0,006. Hasil analisis sig 0,006 lebih kecil daripada 0,05 artinya secara individu variabel perilaku konsumtif berpengaruh signifikan terhadap literasi keuangan.

c. Uji F

Pengujian ini bertujuan untuk mengetahui sejauh mana variabel bebas yang digunakan mampu menjelaskan variabel terikat. Dalam penelitian ini yaitu konsep diri (X1), kecerdasan (X2), perilaku konsumtif (X3) secara bersama-sama atau simultan berkaitan terhadap variabel terikat yaitu literasi keuangan (Y), dan apakah model tersebut sesuai atau tidak. Untuk memberikan interpretasi terhadap uji $f$ dapat dijelaskan pada tabel berikut:

Tabel 4.7

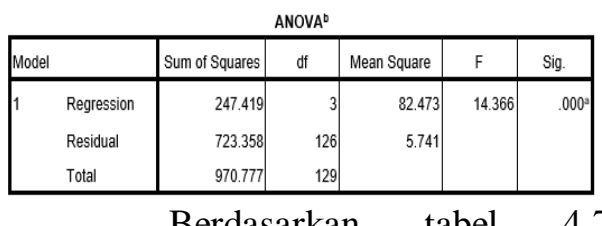

didapat nilai $\mathrm{F}$ hitung 14,366 dengan F sig. 0,000 dimana F sig. 0,000 lebih kecil daripada 0,005 maka $\mathrm{H}_{0}$ ditolak. Dapat diartikan bahwa secara simultan konsep diri (X1), kecerdasan (X2), perilaku konsumtif (X3) berpengaruh signifikan terhadap literasi keuangan (Y).

\subsection{Pembahasan}

Sesuai dengan data pada analisa regresi berganda dan uji hipotesis, diperoleh informasi sebagai berikut:

1. Penelitian ini bertujuan untuk mengetahui pengaruh konsep diri, kecerdasan dan perilaku konsumtif terhadap literasi keuangan. Penelitian ini dilaksanakan di SMK Lingga Kencana Depok. dari data yang diperoleh dengan jumlah sampel 130 siswa sebagai responden.

2. Pengujian selanjutnya adalah pengujian multikoliniearitas data. Melalui pengujian yang telah dilakukan, berdasarkan hasil pengujian tersebut menunjukkan bahwa baik konsep diri, kecerdasan dan perilaku konsumtif memiliki nilai tolerance kurang dari 1 dan VIF memiliki nilai kurang dari 10 maka dapat dikatakan data tidak mengalami multikolinearitas.

3. Hasil koefisien determinasi $\mathrm{R}^{2}$ menunjukkan nilai sebesar sebesar 0,255 yang berarti bahwa pengaruh variabel independen terhadap variabel dependen adalah sebesar 25,5\%. Hal ini memberikan asumsi bahwa pengaruh variabel independen terhadap variabel dependen sebesar $25,5 \%$ dan sisanya 74,5 $\%$ dipengaruhi oleh faktor lain di luar dari penelitian ini. 
4. Hipotesis menunjukkan bahwa terdapat pengaruh antara konsep diri, kecerdasan, perilaku konsumtif terhadap literasi keuangan siswa SMK Lingga Kencana Depok. $\mathrm{H}_{\mathrm{a}}$ diterima dan $\mathrm{H}_{0}$ ditolak.

5. Kondisi ini sejalan dengan hasil penelitian sebelumnya yang mengatakan bahwa literasi keuangan, konsep diri dan budaya secara bersama-sama berpengaruh terhadap perilaku konsumtif besarnya pengaruh ketiga variabel tersebut secara simultan sebesar 8,6\% (Theodorus Mawo, Partono Thomas, dan St. Sunarto, 2017). Kondisi sejenis terdapat pada penelitian dengan judul Pengaruh Financial Literacy terhadap perilaku konsumtif siswa SMA Muhammadiyah Program Khusus Kottabarat Tahun Ajaran 20216/2017, dengan hasil financial literacy berpengaruh posistif dan signifikan terhadap perilaku konsumtif sebesar 17,1 $\%$ (Haryuning Mulatsih Saputri, 2017).

\section{PENUTUP}

\subsection{Kesimpulan}

Penelitian ini dilakukan untuk mengetahui pengaruh veriabel konsep diri, kecerdasan dan perilaku konsumtif terhadap literasi keuangan di SMK Lingga Kencana Depok. kesimpulan yang diperoleh adalah secara parsial variabel konsep diri berpengaruh terhadap literasi keuangan dengan tingkat signifikansi $\quad 0,011<0,005$, variabel kecerdasan berpengaruh terhadap literasi keuangan dengan tingkat signifikansi $0,000<0,005$ dan variabel perilaku konsumtif berpengaruh terhadap literasi keuangan dengan tingkat signifikansi $0,006<0,005$.

Secara simultan konsep diri, keceerdasan dan perilaku konsumtif berpengaruh terhadap literasi keuangan yang dibuktikan dengan tingkat signifikansi sebesar $0,000<0,005$ dan koefisien determinasi $\mathrm{R}^{2}$ menunjukkan nilai 0,255 bahwa pengaruh variabel independen terhadap variabel dependen sebesar 25,5\%. memberikan asumsi bahwa pengaruh variabel independen terhadap variabel dependen sebesar $25,5 \%$ sedangkan sisanya $74,5 \%$ dipengaruhi oleh faktor luar dari penelitian ini.

\subsection{Saran}

Berdasarkan hasil kesimpulan penelitian tentang pengaruh konsep diri, kecerdasan dan perilakau konsumtif terhadap literasi keuangan di SMK lingga kencana Depok, peneliti mengemukakan saran yang dapat dalam penelitian ini adalah sebagai berikut:

1. Bagi Siswa

seluruh responden yang merupakan konsumen dengan usisa beranjak dewasa, mendapatkan ilmu dari banyak aktivitas, sadar penting nya informasi terkait ekonomi dan memiliki wawasan pengelolaan keuangan.berpengaruh besar dalam mengatur keuangan yang didapat dan dimiliki pada masa mendatang.

2. Bagi Peneliti Selanjutnya

Bagi para peneliti selanjutnya diharapkan untuk meneliti lebih mendalam tentang variabel literasi keuangan dengan menambahkan atau mengganti variabel lain dalam penelitiannya guna mengetahui dan meperbaharui pengaruh variabel lain terhadap variabel literasi keuangan sehingga dapat menyempurnakan penelitian ini.

3. Bagi Masyarakat

Orang tua diharapkan mengarahkan anak mereka berkonsumsi secara efisien dalam memenuhi kebutuhannya keuangan bulanan dengan baik agar bisa disisihkan sebagian untuk menabung.

\section{DAFTAR PUSTAKA}

Anissa, Nova. \& Handayani, A. 2012. Hubungan antara Konsep Diri Dan 
JRNAL ПMПAH

Sammandald
P-ISSN 2615-6849, E-ISSN 2622-3686

Jurnal Semarak,Vol.4,No.3,Oktober 2021, Hal (45-54 )

@Prodi Manajemen Fakultas Ekonomi Universitas Pamulang
Kematangan Emosi Dengan Penyesuaian Diri Istri Yang Tinggal Bersama Keluarga Suami. Jurnal Psikologi, Volume 1 Nomor 1 Juni 2012.

Aprilia, D., \& Hartono. (2014). Analisis Sosiologis Perilaku Konsumtif Mahasiswa (Studi pad a Mahasiswa FISIP Universitas Lampung). Jurnal Sosiologi, 15(1), 72-86.

Dewi, N., Rusdarti, \& Sunarto, S. (2017). Pengaruh Lingkungan Keluarga, Teman Sebaya, Pengendalian Diri dan Literasi Keuangan Terhadap Perilaku Konsumtif Mahasiswa. Journal of Economic Education. 6(1): 29-35.

Fatimah, Siti Nur. (2012). Dinamika Konsep Diri Pada Orang Dewasa. Jurnal Vol.1 No.1. Yogyakarta: Fakultas Psikologi Universitas Ahmad Dahlan Yogyakarta.

Fitriyani, Nur., Prasetyo Budi Widodo, 2013. "Hubungan Antara Konformitas Dengan Perilaku Konsumtif Pada Mahasiswa Di Genuk Indah Semarang”. Jurnal Psikologi Undip, 12(1), 56-59.

Ghufron \& Risnawita. (2011). TeoriTeori Psikologi. Yogyakarta: Ar-Ruzz Madia.

Gunartin, G., Wahyu, I. P., Hermawati, R., Handayani, R., Pasaribu, V. L. D., Sunarsi, D., ... \& Maddinsyah, A. (2021). The Effect of Motivation, Leadership, and Job Satisfaction Toward Employee's Performance in the Directorate General of Immigration of the Central Office of Jakarta.

Huston, Sandra J. 2010. "Measuring Financial Literacy". Journal of Consumer Affairs,44(2), 307-318.

Imawati, dkk. (2013). Pengaruh Financial Literacy Terhadap Perilaku Konsumtif Remaja Pada Program IPS SMA Negeri 1 Surakarta Tahun Ajaran 2012/2013. Jurnal Pendidikan Ekonomi- BKK Akutansi, FKIP Universitas Sebelas Maret, 2 (11), hlm. 48-58.
Krisnaldy, K., Pasaribu, V. L. D., \& Senen, S. (2019). Pengaruh Budaya Organisasi, Lingkungan Kerja Dan Iklim Organisasi Terhadap Motivasi Pegawai Serta Dampaknya Terhadap Kepuasan Kerja. Jurnal Semarak, 2(2), 164-183.

Krisnaldy, K., Pasaribu, V. L. D., \& Batubara, A. S. (2020). Analisis Pengaruh Kedisiplinan Terhadap Performa Pegawai Kelurahan Rempoa, Kota Tangerang Selatan. Jurnal Mandiri: Ilmu Pengetahuan, Seni, Dan Teknologi, 4(2), 131-138

Kozina, ,Nina.(2014). “Students' Confidence In Their Financial Manajemen Abilities : The Role Of Socio-Demographic Characteristics And Education". Journal of Problems of Education, Vol.58.h.108.

Kusumaningtyas, Indarti dan Norida Canda Sakti. (2017). Pengaruh Literasi Keuangan Dan Gaya Hidup Terhadap Perilaku Konsumtif Siswa Kelas XI IPS Di SMA Negeri 1 Taman Sidoarjo. Jurnal Pendidikan Ekonomi. 5(3): 1-8.

Lusardi, Annamaria. 2010. "Financial Literacy among the Young: Evidence and Implication for Consumer Policy)". The journal of Consumer Affairs, 49(3),639659.

Margaretha, (2015). Tingkat Literasi Keuangan pada Mahasiswa S-1 Fakultas Ekonomi. Jurnal Universitas Trisakti Vol. 17, No. 1, Maret 2015: 79

Mawo, Theodorus, Partono Thomas dan St. Sunarto. (2017). Pengaruh Literasi Keuangan, Konsep Diri dan Budaya Terhadap Perilaku Konsumtif Siswa SMAN 1 Kota Bajawa. Journal of Economic Education. 6(1): 60-65.

Mendari, Anastasia Sri dan Suramaya Suci Kewal (2014), Tingkat Literasi Keuangan di Kalangan Mahasiswa STIE MUSI. Jurnal Economia, Vol 9, No. 2. 
JRNAL ПMПAH

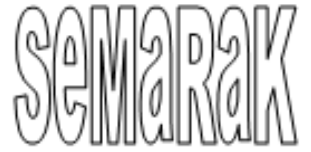

P-ISSN 2615-6849, E-ISSN 2622-3686

Jurnal Semarak,Vol.4,No.3,Oktober 2021, Hal (45-54 )
Mohammad Ali dan Mohammad Asrori. Psikologi Remaja Perkembangan Peserta Didik. Jakarta: PT. Bumi Aksara. 2012.

Notoatmodjo. Metodologi Penelitian Kesehatan. Rineka Cipta. Jakarta. 2010.

Pasaribu, V. L. D., \& Krisnaldy, K. (2018). ANALISIS KEPUASAN JAMA'AH PADA KINERJA DEWAN KEMAKMURAN MASJID ALHIDAYAH PERIODE TAHUN 2017. KREATIF: Jurnal Ilmiah Prodi Manajemen Universitas Pamulang, 6(4), 41-51.

Pasaribu, V. L. D., Krisnaldy, K., \& Warasto, H. N. (2020). Pengaruh Gaya Kepemimpinan, Disiplin Kerja Dan Kompensasi Terhadap Kinerja Pegawai (Studi kasus kelurahan Pisangan Ciputat). Jurnal Disrupsi Bisnis: Jurnal Ilmiah Prodi Manajemen, Fakultas Ekonomi, Universitas Pamulang, 3(1).

Pasaribu, V. L. D., \& Yanuarso, B. P. (2021). PENGARUH STRES KERJA DAN DISIPLIN KERJA TERHADAP KINERJA KARYAWAN PADA PT. MULTRITRAN ABADI SRENGSENG JAKARTA BARAT PERIODE 2018. Jurnal Sekretari Universitas Pamulang, 8(1), 60-72.

Rombe, Sufrihana. 2014. Hubungan Body Image dan Kepercayaan Diri dengan Perilaku Konsumtif pada Remaja Putri di SMK Negeri Samarinda, Jurnal Psikologi, Vol. 2 No.1.76-91.

Triyaningsih, SL. 2011. Dampak Online Marketing melalui Facebook terhadap Perilaku Konsumtif Masyarakat. Jurnal Ekonomi dan Kewirausahaan Vol. 11, No. 2, Oktober 2011: 172 - 177.

Saputri, Haryuning Mulatsih, Siswandari dan Binti Muchsini. (2017). Pengaruh Financial Literacy Terhadap Perilaku Konsumtif Siswa SMA Muhammadiyah
Program Khusus (PK) Kottabarat Surakarta. Jurnal Tata Arta. 3(2): 85-94.

Setiawati, Merak.2016. Pengaruh Kecerdasan, Pengetahuan Ekonomi, dan Perilaku Konsumtif Terhadap Literasi Keuangan Pada Siswa Kelas XI IPS SMA Negeri Sekota Madiun. Tesis. Universitas Sebelas Maret. Surakarta.

Sugiyono. (2017). Metode Penelitian Kuantitatif, Kualitatif, dan R\&D. Bandung :

Veiga, F., \& Leite, A. (2016). Adolescents' self-concept short scale: A version of PHCSCS. Procedia-Social and Behavioral Sciences, 217, 631-637.

Zakiah, Farah. 2013. Pengaruh Kecerdasan Intelektual Kecerdasan Emosional Kecerdasan Spiritual Terhadap Pemahaman Akuntansi. 